\title{
The Development of Local Land Information Systems in the Rural Municipalities
}

\section{Introduction}

In the last ten years there has been observed a significant activity in creating regional and local LIS in Poland [3]. This is due to a trend of Spatial Data Infrastructures (SDI) development. In accordance with the definition adopted in the INSPIRE Directive [7] 'infrastructure for spatial information' means: metadata, spatial data sets and spatial data services; network services and technologies; agreements on sharing, access and use and coordination and monitoring mechanisms, processes and procedures, established, operated or made available in accordance with this Directive. All of the European Union members are obligated to launch National Spatial Data Infrastructures (NSDI). INSPIRE Directive defined the scope of thematic SDI data contained in three annexes to the Directive and the timeliness to implement the data.

The Article 9 of the INSPIRE Directive says that the implementing rules shall be adopted in accordance with the following timetable:

a) no later than 15 May 2009 in the case of the spatial data sets corresponding to the themes listed in Annex I;

b) no later than 15 May 2012 in the case of the spatial data sets corresponding to the themes listed in Annex II or III.

Municipalities are responsible for implementing of local spatial development plans. Spatial data should be published in conjunction with all rules on Annex III to the Directive. This European mobilization positively influenced on development of Land Information Systems and consequently on all kind of SDI [6].

These mentioned activities are the result of the global trend towards building the Information Society and Spatially Enabled Society [9]. It is linked with the need to strive the sustainable development [26].

* University of Warmia and Mazury in Olsztyn, Faculty of Geodesy, Geospatial and Civil Engineering, Department of Real Estate Resources, Olsztyn, Poland 
Since the nineties comprehensive research has been conducted on the usefulness of Geographical Information Systems for local governments and their citizens [8, 10, $11,13,28,30]$. This work resulted in the massive development of the GIS and information services.

Nowadays Land Information System (LIS) is a part of a developing society. These systems build relationships between the institutions. They can also be seen as a tool to achieve goals of the common European strategy on EUROPE 2020 in terms of smart, sustainable and inclusive growth and in the building a digital society in Europe and Millennium Development Goals [25] or Sustainable Development Goals [27]. The use of land information systems affects the innovative capacity in both urban and rural areas. Information systems are also the basis for the dissemination of data, information, knowledge, and for implementing a wide range of services in relations between local community - entrepreneurs, local community - local authorities, and finally local authorities - entrepreneur. These systems can be included to a group of information systems that support decision-making processes.

In Poland the mission of the Ministry of Digital Affairs is to create a digital boost for the development in Poland. This ministry also develops new e-services and promotes digital reference for citizens. Modern administration should be based on digitization. Digitization promotes equal opportunities for all citizens and also digitization is the key to modern administration [15]. Spatially enabled encourages the development of innovation, transparency and democracy in the country. In connection with the chosen development direction we can talk about the onset of the spatial information revolution. Citizens and their governments must be spatially enabled, have the right tools and information within easy reach to make the right decisions.

ePUAP (The Electronic Platform of Public Administration Services) is a system that provides administrative services to the citizens. The goals of the ePUAP are: increasing the number of public services available on-line; promoting the use of on-line services; integrating different public administration services. Citizens can use an ePUAP from their houses if their have Internet access. Citizens can have some benefits from an ePUAP. These benefits for example are: access to many public administration services from one location; arranging official matters over the Internet; access to document which are required by public administration [16]. E-administration taking place in the Europe Union. Each country creates e-administration in their way [21]. An international study shows that improving interactions though e-administration at the local level can increase trust in government [24]. Studies show that it is possible that social norms in rural areas and in urban areas are different. This norms may have an impact on people's intention to use online services [23].

Digitization is a process of transformation paper data to a digital form. One kind of this data are data about land and location. Informatization in Poland started formally in 2005, that year an Act was established about informatization activities of 
entities performing public tasks [1]. Regulation of the Council of Ministers regarding the State Informatization Plan for 2006 [22] was created in 2006. That Regulation started an informatization/digitization in Poland. Municipalities in Poland take part in informatization/digitization of data. The municipalities have started building their own spatial information systems for local needs. These systems provide information that can be used in decision-making processes. The municipalities can make web mapping portals which are available for many groups of users.

E-administration may help officials to better manage their workload. The service time can be faster than when the applicant visit office [29]. E-government works through IT application [20]. E-government produces and delivers different services.

This paper presents best practices in the establishment of the local web mapping services using LIS data in rural communes. It also presents opportunities and directions for using the Land Information Systems. It is an attempt to present of use the Land Information Systems in web mapping. Land Information Systems and web mapping services are available for many groups of users. These systems are necessary in the process of social activation. At present it is necessary to use the latest technical developments related to the sharing of information, including spatial information.

\section{Materials and Methods}

One of the main objectives of this study is to assess that the two selected LIS are a local part of National Spatial Data Infrastructures (NSDI). The analysis covered the organizational and technical area of action in geoportals at the commune level.

In Poland there is a three-tier administrative division of the country, where the largest surface of local government units are the region (Voivodeship) (16). The smaller unit are counties (poviats) (380), and the smallest municipality (2479/8) (data from TERYT - National Register of Country Territorial Division on 2014) [14]. These units have their own tasks for example: gathering and redistributing information. Figure 1 presents administrative division of Republic of Poland.

There are 1563 rural municipalities and there are 611 urban-rural municipalities with rural areas. The population density per $1 \mathrm{~km}^{2}$ in Poland equals 123 persons; it has not changed since 2014. In rural areas population density per $1 \mathrm{~km}^{2}$ in Poland equals 52 persons. The most populated voivodeship are: małopolskie (128 persons $\left./ 1 \mathrm{~km}^{2}\right)$ and śląskie (122 persons $\left./ 1 \mathrm{~km}^{2}\right)$. The least populated voivodeship are: lubuskie, podlaskie, warmińsko-mazurskie and zachodniopomorskie.

The choice of these two LIS was not accidental. Tested land information systems are in municipalities located in the north-east of the Warmia and Mazury Region (Fig. 2) (one of the poorest region in Poland) and they are:

- SIP Stawiguda (Stawiguda Municipality) [18],

- SIP Dywity (Dywity Municipality) [19]. 

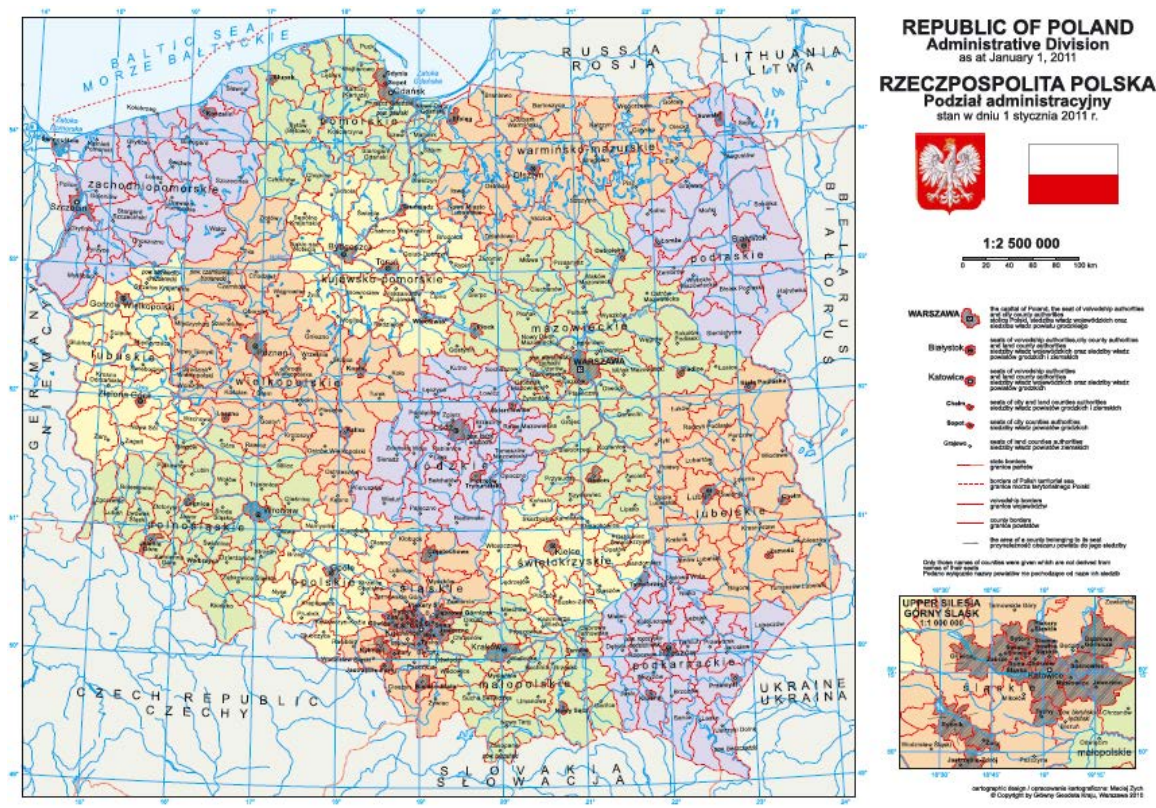

Fig. 1. Administrative division of Republic of Poland - as at January 1, 2011

Source: [12]

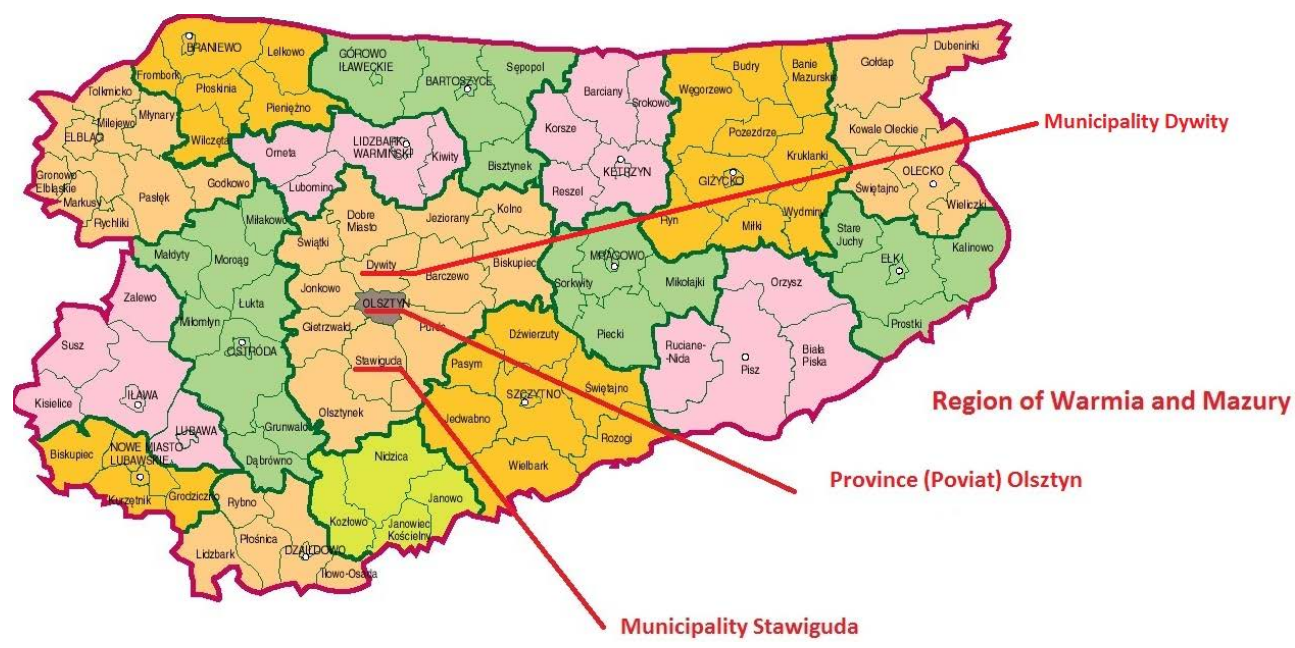

Fig. 2. Warmia and Mazury Region

Source: A. Dawidowicz on the basis of KSNG [12]

Table 1 presents the main conditions of municipalities whose information services was adopted to compare. 
Table 1. Conditions of Stawiguda and Dywity Municipalities

\begin{tabular}{||l|c|c||}
\hline \multicolumn{1}{|c|}{ Conditions } & Municipality Stawiguda & Municipality Dywity \\
\hline \hline Area $\left[\mathrm{km}^{2}\right]$ & 222.52 & 160.68 \\
\hline Location in the region & warmińsko-mazurskie & warmińsko-mazurskie \\
\hline Type of municipality & rural & rural \\
\hline Population & 6440 & 10,411 \\
\hline Density of population [person $\left./ \mathrm{km}^{2}\right]$ & 28.9 & 64.8 \\
\hline Percentage of agricultural land $[\%]$ & 23 & 60 \\
\hline Percentage of forests [\%] & 54 & 25 \\
\hline
\end{tabular}

Source: data from the Central Statistical Office [17]

These two municipalities built their own LIS because of the UE Founding Project on Information system for broadband infrastructure and portal Broadband Poland, carried out under the $7^{\text {th }}$ priority axis of the Operational Programme Innovative Economy in 2009. The aim of the project was to create a Teleinformation infrastructure with nationwide coverage, providing support to central and local government on the development of broadband infrastructure (backbone and access) in areas requiring intervention and information society services. This infrastructure and its information resources support the activities of both government administration and local government, creating facilities for electronic public services (ePUAP) provided for citizens and business. An additional objective of the project was to promote the information society services among citizens in areas at risk of digital exclusion.

The aim of the study was to compare the thematic resources, available services, tools and skills to make use of two local Land Information Systems. The characteristics taken into account include the general range of thematic data and metadata provided by portals, available tools, and services related to the use of these data. These methodology was previously used to evaluate chosen national geoportals $[2,5]$. In view of the variety of solutions offered by web mapping services and increasingly larger needs of citizens in the use of spatial data, were also examined all services offered by the chosen LIS in the range of personalization. Due to the constantly evolving branch services designed for mobile devices, the assessment also included the ability to download applications from the SDI portals to mobile devices.

\section{Results and Discussion}

\subsection{Land Information System - SIP Stawiguda}

Digital spatial development information system was introduced in municipality of Stawiguda in 2013. This system presents spatial information within borders of the commune. It is a source with variety of spatial information. It combines cadastral 
and topographic information with orthophotomap as well as current master (land use) plans. Web mapping service - SIP Stawiguda gives a view of different combined layers like: cadastral map (Fig. 3), land use plan (Fig. 4), orthophotomap (Fig. 5).

This system has also a search tool, that helps to find: area of chosen village, chosen plot, chosen land use plan (with its whole description is attached in a file including symbols and parameters). SIP Stawiguda also provides tools necessary for printing current view, saving links, identifying objects as well as measuring distances and areas.

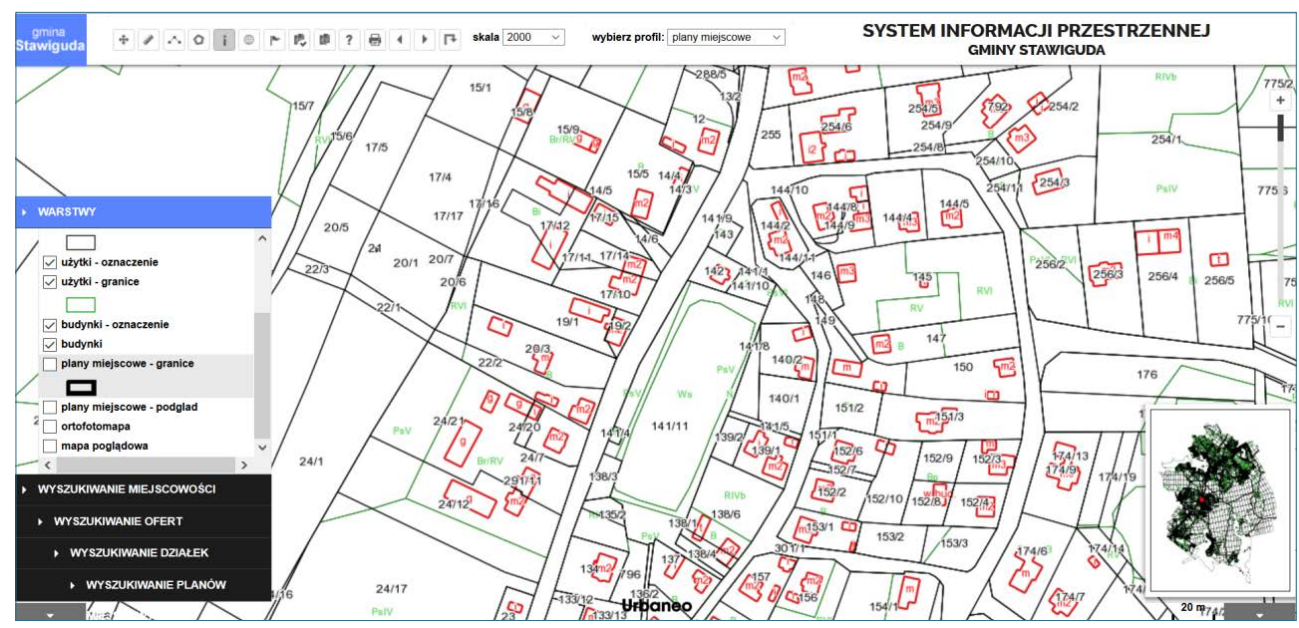

Fig. 3. Chosen layers on a SIP Stawiguda view - cadastral map Source: [18]

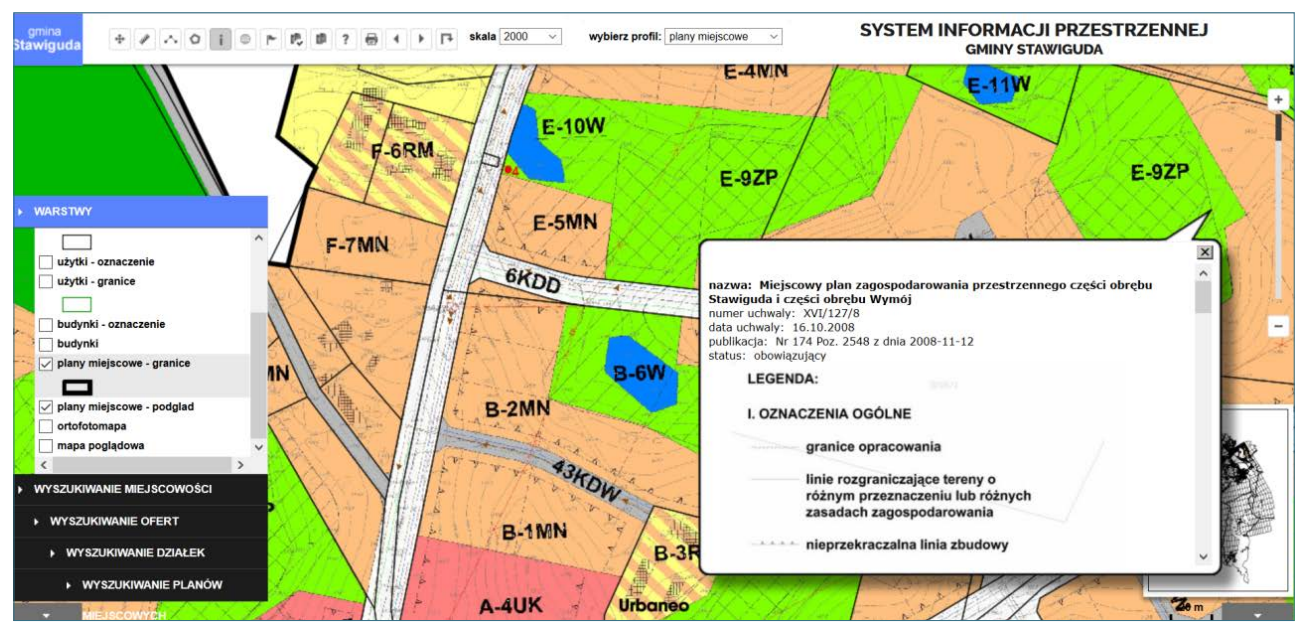

Fig. 4. Chosen layers on a SIP Stawiguda view - land use plan

Source: [18] 


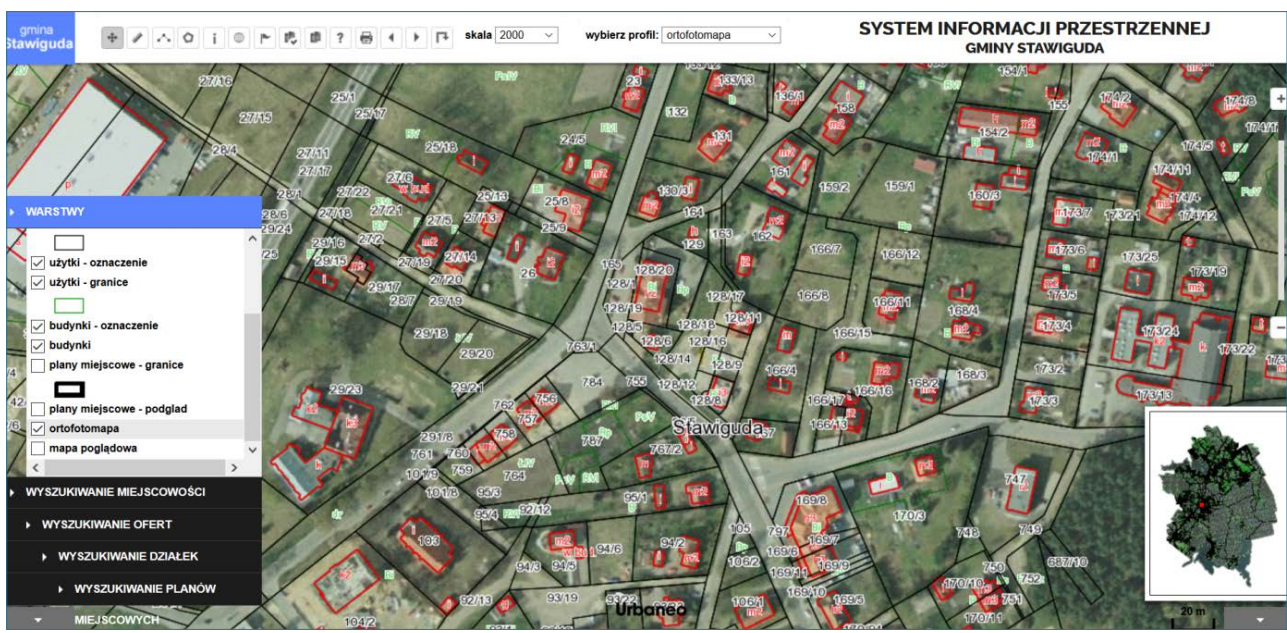

Fig. 5. Chosen layers on a SIP Stawiguda view - orthophotomap and cadastral map Source: [18]

\subsection{Land Information System - SIP Dywity}

This LIS provides information about land use plans (Fig. 6), address and data of the buildings. SIP Dywity also provides information about areas that are protected landscape of e.g. the Łyna River. Users can search for a location of a plot, number of building, or for data space using GPS coordinates.

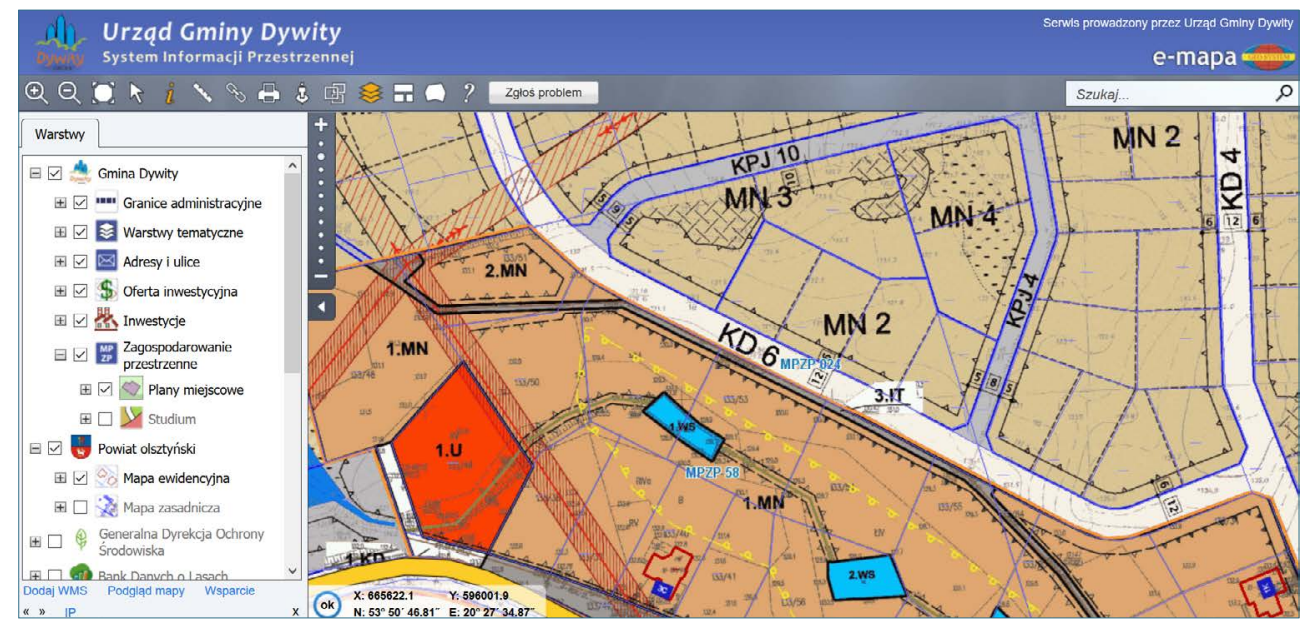

Fig. 6. Chosen layers on a SIP Dywity view - land use plan 
For more discerning users the system presents satellite images, topographic database, hydrological maps, sozological and forest maps (Fig. 7) and well known street view service offered by Google maps.

Street view covers the majority of municipality roads. SIP Dywity is in process of filling the database on POIs including bike trails, green waste collection points, rural tourism, offices, schools, trades, services and other data. The system will also find a link to the investment proposal of Dywity Municipality.

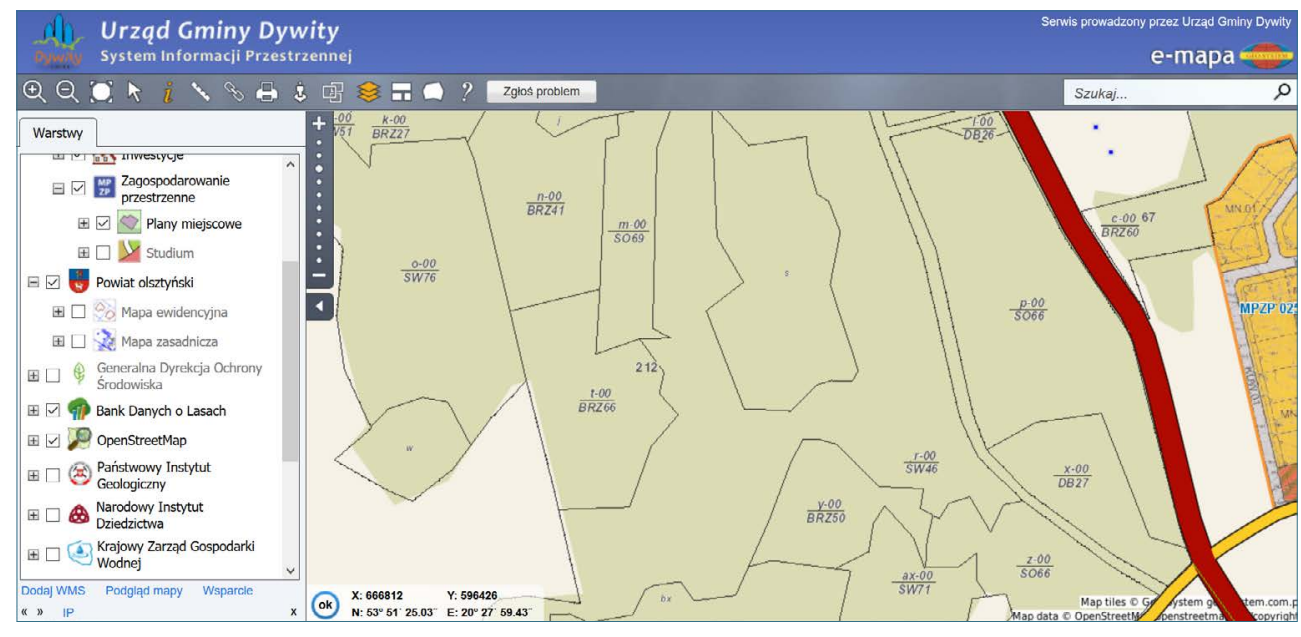

Fig. 7. Chosen layers on a SIP Dywity view - forest map

Source: [19]

\subsection{Land Information Systems Comparison}

The attributes of LIS to conduct a research have been adopted on the basis of Cichociński et al. [3]. The intention of the authors was to identify differences without determining the weight of each attribute. Testing took place on 25 March 2016. The test results are presented in Table 2 and in the Figure 8. A " $x$ " indicates that a factor is present in the web mapping service, while " - " means the absence of the desired item.

The services present a different level of functionality in spite the fact that they obtained funds from the same source. SIP Stawiguda turns out to be much weaker. This is probably due to the wealth of a municipality stemming from the number of residents. It has been observed that the more populated municipality, there is greater need for more comprehensive service. Municipality Stawiguda is located in the attractive tourist areas with many lakes and forests, so there is less land to settle down and invest and less money to conduct a web mapping service. Local governments have noted increased interest in the municipality land since when have been running services. Created services serve to municipal governments for effective land management. 
Table 2. Functionality of chosen web mapping services

\begin{tabular}{|c|c|c|c|}
\hline & \multirow{2}{*}{ Attribute } & \multicolumn{2}{|c|}{ Type of geoportal } \\
\hline & & \multirow{2}{*}{$\begin{array}{c}\text { SIP Stawiguda } \\
-\end{array}$} & \multirow{2}{*}{$\begin{array}{c}\text { SIP Dywity } \\
-\end{array}$} \\
\hline \multirow{14}{*}{ 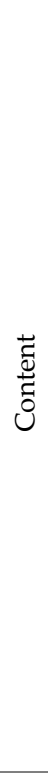 } & Sectoral module & & \\
\hline & INSPIRE module & - & $\times$ \\
\hline & Statistical module & - & - \\
\hline & Data from EuroBoundaryMap & - & $x$ \\
\hline & State Register of Geographical Names & $x$ & $\times$ \\
\hline & The cadastral data & $\times$ & $x$ \\
\hline & Surface relief & $\times$ & $x$ \\
\hline & General Geographic Database & $x$ & $x$ \\
\hline & Vector map & - & - \\
\hline & The database of topographic objects & - & $\times$ \\
\hline & Thematic maps & $x$ & $x$ \\
\hline & Scans of topographic maps & - & $x$ \\
\hline & Orthophotomap & $\times$ & $\times$ \\
\hline & Data on basic control networks & - & - \\
\hline \multirow{17}{*}{$\begin{array}{l}\frac{\infty}{8} \\
0 \\
0\end{array}$} & Adjust the map to the selected area & $x$ & $\times$ \\
\hline & Adjust the map to the selected selection & - & $\times$ \\
\hline & The form of data presentation [2D/3D] & $2 \mathrm{D}$ & $2 \mathrm{D}$ \\
\hline & Thumbnail/ image preview & $x$ & $x$ \\
\hline & Panel of layers & $x$ & $x$ \\
\hline & Legend & - & $\times$ \\
\hline & Back/ back to the start page & $x$ & $x$ \\
\hline & Retry & $\times$ & $x$ \\
\hline & Zoom/ zoom to selected area & $\times$ & $x$ \\
\hline & Zoom to selected object & - & $x$ \\
\hline & Inserting a class ranges & - & - \\
\hline & Reduction & $x$ & $\times$ \\
\hline & Moving the map cursor & $x$ & $x$ \\
\hline & Moving the map by clicking on the frame & - & $x$ \\
\hline & Centering & $\times$ & $\times$ \\
\hline & Removal of selection & $x$ & $\times$ \\
\hline & Selection & $x$ & $\times$ \\
\hline
\end{tabular}


Table 2. cont.

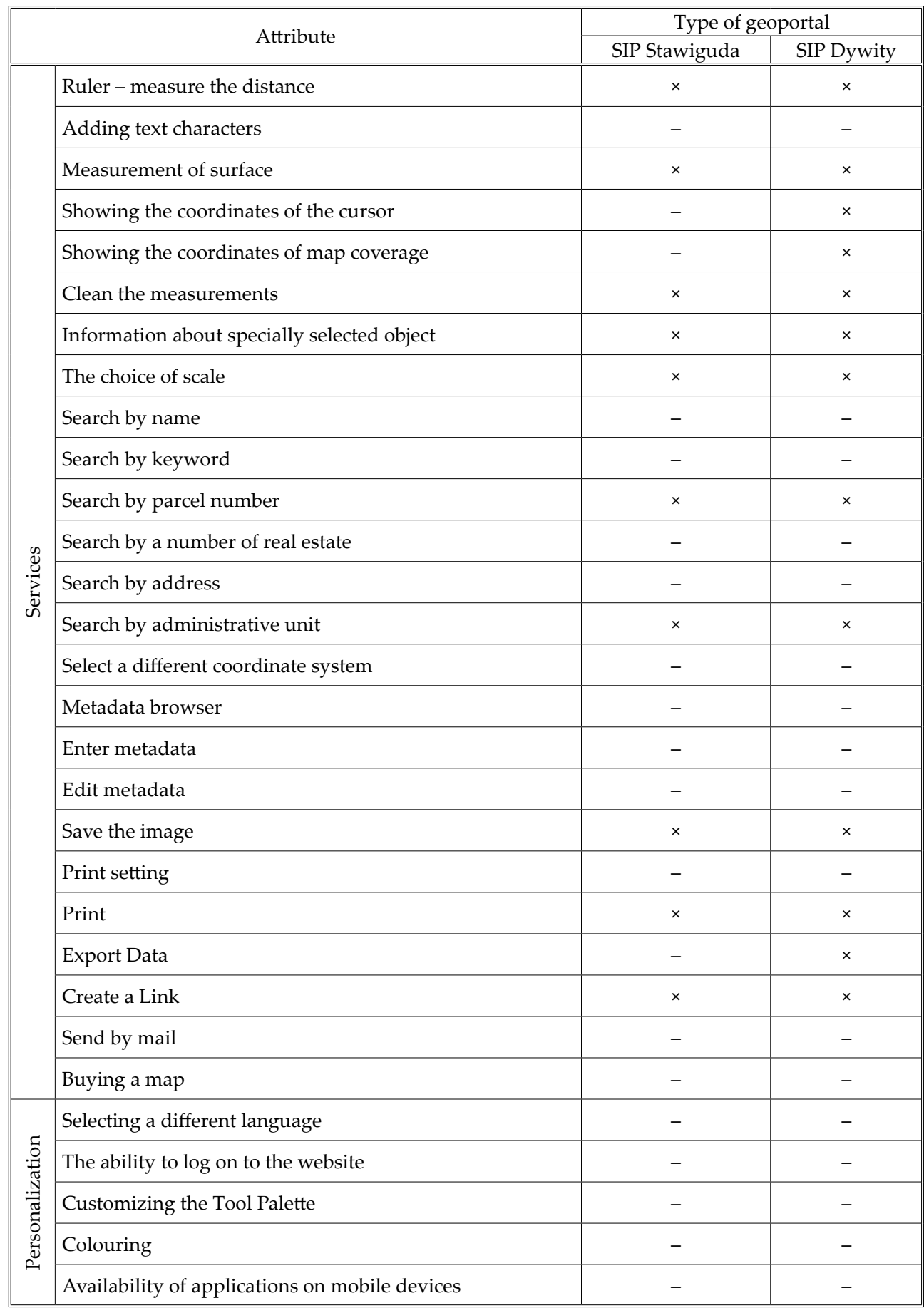




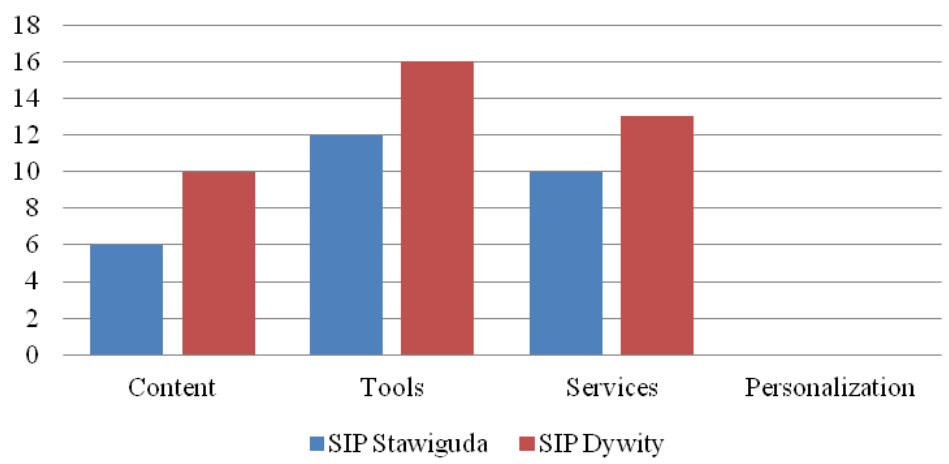

Fig. 8. The functionality rating of the web mapping services

\section{Conclusions}

As it was confirmed by numerous studies, creating and using of spatial information systems positively affects the formation of innovative activity both in urban and rural areas. These systems as it turns out, are not only used to collect data on land, but also for their distribution by created web map services.

The carried out comparative analyzes allow to express the wide conclusions. The examined local land information systems (web mapping services) in rural commune are designed successfully. They work efficiently by serving a few dozen hits per day. This LIS are functionally adapted to the local users, such as local public entities, investors and property owners. They contain data necessary for local development. The services are running smoothly. A measurable benefit of having web mapping services in the areas of both municipalities is a noticeable increase of investments. There is a high probability that on this situation mapping services had an impact.

LIS were created despite the existing national services and are continuously being improved to meet the needs of users. Thanks to its simplicity it is easier to use and understand them by inexperienced users. The local governments are opening their own LIS, because national Integrated Real Estate Information System (Project ZSIN [4]) has not been lunched yet. This means that spatial data on land is necessary for proper land management.

There is no access to local spatial development plans from one place, through a common broker in the national level. It is expected that in the near future local spatial development plans will also operate in the structure of the data flow through the ZSiN in Poland. Thus, the measurable benefit of having local LIS is the ability to quickly attach data from the local to the national Spatial Data Infrastructure (SDI). This will be possible because analyzed LIS operate in accordance with the INSPIRE Directive creating local SDI. INSPIRE Directive imposes uniform standards for recording and exchange of spatial data. 


\section{References}

[1] Act of 17 February 2005 on informatization activities of entities performing public tasks. Journal of Laws 2014 item 1114 [Obwieszczenie Marszałka Sejmu Rzeczypospolitej Polskiej z dnia 26 czerwca 2014 r. w sprawie ogłoszenia jednolitego tekstu ustawy o informatyzacji działalności podmiotów realizujacych zadania publiczne. Dz.U. 2014, poz. 1114].

[2] Adamczyk T., Begović V., Bieda A., Bielecka E., Bugaj P., Dawidowicz A., Džunić I., Gajos M., Jankowska M., Kereković D., Krukowska K., Kryszk H., Kurowska K., Parzych P., Rahmonov O., Schrunk I., Wójciak E., Źróbek R.: Spatial Data in Wide Geospace. Nacionalna knjižnica, Zagreb 2014.

[3] Cichociński P., Dawidowicz A., Mika M., Ogryzek M., Salata T., Siejka M., Ślusarski M., Wolny A.: Geoinformation technology and data models. Nacionalna knjižnica, Zagreb 2015.

[4] Dawidowicz A., Džunić I. Polish and Croatian way to land administration systems - a case study. [in:] GIS and Its Implementations, Nacionalna knjižnica, Zagreb 2013, pp. 5-19.

[5] Dawidowicz A., Sońta M. 2014. Analiza porównawcza wybranych geoportali europejskich. ActaScientiarum Polonorum. AdministratioLocorum, 13(2), 2014, pp. 59-76.

[6] Dawidowicz A., Źrobek R.: Hierarchical development of the Spatial Data Infrastructures as a globalization trend. [in:] Proceedings: 2016 Baltic Geodetic Congress (Geomatics). BGC Geomatics 2016, IEEE, Gdansk 2016, pp. 147-153. doi: 10.1109/BGC.Geomatics.2016.34, [on-line]: http://ieeexplore.ieee.org/stamp/ stamp.jsp?tp=\&arnumber=7548020\&isnumber=7547886 [access: 10.09.2016].

[7] Directive 2007/2/WE of the European Parliament and Council, of March 14th 2007, establishing the infrastructure of Spatial Information in the European Community (INSPIRE). OJ L 108, 25.4.2007.

[8] Elwood S., Leitner H.: GIS and Community-based Planning: Exploring the Diversity of Neighborhood Perspectives and Needs. Cartography and Geographic Information Systems, vol. 25, issue 2, 1998, pp. 77-88.

[9] FIG: Spatially Enabled Society. Steudler D., Rajabifard A. (eds.), FIG Publication No. 58, FIG Press, Copenhagen 2012.

[10] Harris T.M., Weiner D., Levin R.: Pursuing social goals through participatory GIS: Redressing South Africa's historical political ecology. [in:] Pickles J. (ed.), Ground truth: The social implications of geographic information systems, Guilford, New York 1995, pp. 196-222.

[11] Hyman G., Leclerc G., Beaulieu N.: GIS for Sustainable Development at Local Scales: Applications in the Rural Hillsides, Savannas and Forest Margins of Latin America [paper for the 19th Congress of the International Society for Photogrammetry and Remote Sensing Meeting (ISPRS), Amsterdam, the Netherlands, July 2000]. [on-line:] http://gisweb.ciat.cgiar.org/sig/download/ ghyman/GISforSustainableDevelopmentLocal.pdf [access: 12.09.2016]. 
[12] KSNG (Commission on Standardization of Geographical Names Inside the Republic of Poland): Toponymic guidelines of Poland for map editors and other users. Główny Urząd Geodezji i Kartografii, Warszawa 2010, [on-line:] http:// ksng.gugik.gov.pl/english/tgp.php [access: 25.06.2013].

[13] Kwaku Kyem P.A.: Embedding GIS Applications into Resource Management and Planning Activities of Local and Indigenous Communities. A Desirable Innovation or a Destabilizing Enterprise? Journal of Planning Education and Research, vol. 20 (2), 2000, pp. 176-186.

[14] Link 1. Główny Urząd Statystyczny: www.stat.gov.pl/broker/access/index. jspa [access: 23.03.2016].

[15] Link 2. Ministerstwo Cyfryzacji, e-usługi: https://mc.gov.pl/e-uslugi [access: 23.03.2016].

[16] Link 3. Ministerstwo Cyfryzacji, ePodręcznik: https://epodrecznik.mac.gov. $\mathrm{pl} /$ mediawiki/index.php?title=E-us\%C5\%82uga [access: 23.03.2016].

[17] Link 4. Główny Urząd Statystyczny, portal informacyjny: http://stat.gov.pl/ [access: 10.04.2016].

[18] Link 5. Gmina Stawiguda, System Informacji Przestrzennej: http://sip.stawi guda.pl/mapa/ [access: 10.04.2016].

[19] Link 6. Urząd Gminy Dywity, System Informacji Przestrzennej: http://dywity. e-mapa.net/ [access: 10.04.2016].

[20] Moon M.J.: The Evolution of E-Government among Municipalities: Rhetoric or Reality? Public Administration Review, vol. 62, issue 4, 2002, pp. 424-433.

[21] Pina V., Torres L., Royo S.: E-government evolution in EU local governments: a comparative perspective. Online Information Review, vol. 33, issue 6, 2009, pp. 1137-1168.

[22] Regulation of the Council of Ministers of 1 August 2006 regarding the State Informatization Plan for 2006. Journal of Laws 2006 No. 147, item 1064 repealed [Rozporzadzenie Rady Ministrów z dnia 1 sierpnia 2006 r. w sprawie Planu Informatyzacji Państwa na rok 2006. Dz.U. 2006, nr 147, poz. 1064 uchylone].

[23] Roy M.-C., Charter A., Crête J., Paulin D.: Factors influencing e-government use in non-urban areas. Electronic Commerce Research, vol. 15, issue 3, 2015, pp. 349-363.

[24] Tolbert C.J., Mossberger K.: The Effects of E-Government on Trust and Confidence in Government. Public Administration Review, vol. 66, issue 3, 2006, pp. 354-369.

[25] UN, 2000. United Nations Millennium Declaration. Resolution 55/2. [on-line:] https://documents-dds-ny.un.org/doc/UNDOC/GEN/N00/559/51/ PDF/N0055951.pdf? [access: 5.04.2016].

[26] UN, 2007. Framing Sustainable Development. The Brundtland Report 20 Years On. [on-line:] http://www.un.org/esa/sustdev/csd/csd15/media/ backgrounder_brundtland.pdf [access: 30.03.2016]. 
[27] UN, 2015. Transforming our world: the 2030 Agenda for Sustainable Development.UESustainable Development Agenda, ResolutionA/RES/70/1, [on-line:] http://www.un.org/ga/search/view_doc.asp?symbol=A/RES/70/1\&Lang=E [access: 1.07.2016].

[28] Ventura S.J.: The Use of Geographic Information Systems in Local Government. Public Administration Review, vol. 55, no. 5, 1995, pp. 461-467.

[29] Welch E.W., Charles C., Hinnant C.C., Moon M.J.: Linking Citizen Satisfaction with E-Government and Trust in Government. Journal of Public Administration Research and Theory, vol. 15, issue 3, 2005, pp. 371-391.

[30] Worrall L.: Justifying investment in GIS: a local government perspective. International Journal of Geographical Information Systems, vol. 8, issue 6, 1994, pp. 545-565. 